\title{
The case against land application of sewage sludge pathogens
}

\author{
Maureen Reilly BA \\ University of Toronto, Toronto, Ontario
}

$\mathrm{T}$ here is currently a public debate about whether health, agricultural and environmental authorities should continue to allow sewage sludge to be spread on farmland. Some of the concern in the debate is about the pathogen content of sewage sludge. This concern was heightened by the tragedy at Walkerton where Eschericha coli 0157:H7 and other pathogens contaminated the drinking water supply of this Ontario town. The Canadian public were reminded how vulnerable they can be to disease when agricultural practices ajoin population centres without adequate health and environmental controls.

But pathogens are not the only contaminants of concern in sewage sludge. Sewage sludge also contains potentially harmful levels of toxic metals and environmentally persistent chemicals such as polychlorinated biphenyls and dioxins (1).

In the past, farm application was often not the favoured method of disposal. Sludge was incinerated or landfilled, and only a small percentage was applied to farmland. With air quality concerns increasing and landfill capacity at a premium, municipalities have moved to farm disposal of these waste sludges, especially in Ontario, where almost all wastewater sludges are applied on farms.

Have the risks to human health been adequately evaluated? Should government promote the transfer of these wastes to the countryside? Is it reasonable to ask rural residents to live next to sites where human excrement mixed with industrial waste is stockpiled and spread on the land?

\section{BACKGROUND}

Flush toilets were invented almost 200 years ago, yet we as a society are still trying to manage the health and environmental impact of our own waste. The whole idea of 'public health' developed in response to the contagion created by allowing urban streets to flow with septic wastes. Eventually, the crises in pests, disease and plagues led to the creation of an infrastructure of sewers to remove these wastes and confine them away from the public in a sewage treatment plant.

Over the past 20 years, with the public desire to protect surface waters from sewage contamination, sewage treat- ment plants (accurately renamed wastewater treatment plants) are designed to separate the water in the sewer system from the solids and contaminants, and return the water fraction the lake, river or ocean in a relatively purified form. Sewage sludge, sometimes called 'biosolids', is the solid fraction of this waste. Wastewater treatments plants are not designed to treat the the sludge effectively; they are primarily designed to clean the water fraction.

\section{WHAT 'TREATMENT' IS REQUIRED?}

The industries that promote the placement of sewage on rural and agricultural land like to speak of 'treated' sewage, 'treated' sludge or 'biosolids'. However, there is little in provincial statutes that sets out what 'treatment' may be required before sewage is placed on land. Requirements for sewage treatment vary from one wastewater facility to the next and may or may not be detailed in a Certificate of Approval or permit from the provincial Ministry of the Environment.

In Ontario, septage, which is untreated sewage waste pumped out of septic tanks and abbatoir waste, is also allowed to be spread or sprayed on rural land. No treatment is required.

Often, the Ontario government adopts the American requirement for 'treatment' that the sludge should contain less that two million fecal coliforms colony forming units/g. However, not all sewage treatment plants achieve this level. The Ashbridges Bay Treatment Plant in Toronto, Ontario processes sludge for about 1.7 million people. There are not enough digesters to allow for the recommended minimum 15 to 30 days of digestion of sludge in anaerobic tanks. Therefore, Toronto sewage sludge may receive as little as eight to 10 days of digestion (personal communication, Interim Compliance and Monitoring Committee, City of Toronto, Toronto, Ontario). The Ontario Ministry of the Environment has facilitated the spreading of this sludge with elevated pathogens by allowing the City of Toronto to average the test results according to a specific formula, so rural residents have no assurance that specific standards of disinfection have been met by sludge delivered to farms. 
The fecal coliform levels in the City of Toronto sewage sludge have often exceeded even the above permissive standards. In 1999, levels of fecal coliform exceeded two million colony forming units/g, even when the city was allowed to average the test results over several weeks.

Toronto sewage has been trucked to a facility in Halton, Ontario where it was stored in an open pit the size of a football field. Neighbours of this facility have protested because foul odours have stopped them from being able to leave the house or open the windows. Residents near the facility have become seriously ill with enteric viruses, which they are concerned may be the result of their exposure to the sludge (personal communication, Laura Eagles).

\section{DO WASTEWATER TREATMENT PLANTS 'TREAT' SLUDGE?}

Scientists at the University of Ottawa Faculty of Medicine prepared a research report for the City of Ottawa on whether the Ottawa Pickard Centre sewage treatment plant was effective in reducing pathogens in Ottawa sewage sludge (2). Their report concluded that "it is clear that the pathogen content of biosolids from the Pickard Centre may be relatively high...". The report also concluded that there was no reduction on giardia cyst levels, only a $49.9 \%$ decrease in cryptosporidium oocyst densities and only slightly reduced levels of somatic coliphages, suggesting a similarly small reduction in enteric virus loading in the land applied sewage (3).

A more detailed report on the health risks from pathogens associated with land application of sewage sludge can be found in "Hazards from pathogenic microorganisms on landdisposed sewage sludge" (4), which outlines the range of pathogens found in sludge and their longevity in the soil.

A study of sewage workers at the Toronto Ashbridges Bay Treatment Plant showed increased incidence of disease compared with a similar group of workers not exposed to biosolids (5). The United States National Institute for Occupational Safety and Health has posted a health alert for those who work with biosolids (6). The Journal of Agromedicine also published a report linking odours with health risks (7). The research has implications for those workers, farmers and rural residences who are exposed to sewage sludge.

\section{RISKS FROM SEWAGE SLUDGE}

Venues for pathogen transfer: Land application of sewage sludge can lead to the transport of pathogens through bioaerosols downwind of sludge storage or spreading sites, through contamination of ground water, drinking water wells, stockponds and surface waters, or through food contamination from eating food grown in sludge spread land. Pathogens can be transported to humans who walk through sludge spread fields. Wild animals, farm animals, birds, rodents and pets may become infected by or transmit sludge pathogens. There is no requirement to post signs that sludge has been spread or stored on fields in Canada. Therefore, children, family members and others may access and traverse sludge spread sites unknowingly.
Bioaerosol risk: A recent study from the University of Arizona (8) shows that the risk of windborne pathogens is significant within a $10 \mathrm{~km}$ radius of a sludge spread field. In Canada, the relatively cooler and wetter climate may make this risk even higher.

Risk to water: Sewage sludge contains a high concentration of wastes; indeed, a 100-acre spread of sewage sludge represents the annual fecal output of approximately 1400 people plus the industrial waste component. To compare sludge with manure, a field of similar size would support 100 cattle.

Some provinces have 'guidelines' or other criteria that are intended to address the environmental and health issues related to the land application of sewage sludge. However, these 'guidelines' are not always enforceable, and most are not legally binding. Ontario has one of the most detailed documents on the land application of sewage sludge and other organic waste. However, the Guidelines for the Use of Biosolids and Other Wastes on Agricultural Land (9) are only a 'guidelines'. They are not statutes or regulations. In Ontario, even after the Walkerton tragedy, reductions were allowed in the the separation distances between sludge spreading sites and drinking wells, lakes, rivers and surface waters. Ottawa and Toronto are currently allowed to spread sludge as close as 15 $\mathrm{m}$ to a drilled drinking water well and as close as $15 \mathrm{~m}$ to surface water despite provincial law that stipulates greater, more protective distances (10).

Risk from food: The Ontario Ministry of the Environment and the Ministry of Agriculture recommend that farmers observe a waiting period between sludge spreading and the harvesting of some crops, and recommend that farmers restrict farm animals from fields recently spread with sludge. These recommendations are not enforceable under current legislation. Therefore, sludge spread fields can be used to grow small fruits such as strawberries or pasture livestock, and thus expose the consumer to contaminated produce and meats.

Animal transfer: Farm animals and pets such as cats and dogs can be expected to continue to travel through fields, even after the fields have been spread with sludge, and return to their owner's homes, spreading sewage sludge to the family home. Birds may also visit sludge spread fields, and spread viruses, bacteria and parasites in their subsequent droppings.

\section{ISSUES OF CONCERN}

Lack of research: The Environmental Protection Agency in the United States, the Ontario government and the Water Environment Association of Ontario have all acknowledged that pathogen risks from land application of sewage sludge have not been adequately evaluated. In both Canada and the United States, policies concerning land application are under review for this reason. In the United States, the National Academy of Science is conducting a risk assessment on the land application of sewage sludge. In Ontario, just a few months after Walkerton crisis, the Ontario Ministry of the Environment announced a review of the regulations concerning the land application of sewage sludge, septage and all biosolids. 
Lawsuits in the United States: It is thought that several deaths in the United States have been attributed to the land application of sewage sludge, and lawsuits have been brought (11). One of these cases, concerning the death of Shayne Connor, who lived adjacent to a sewage sludge spreading site, is currently making its way through the New Hampshire courts. Other lawsuits involving livestock deaths have also been filed in Georgia.

Regrowth: A study conducted in Australia in 1997 looked at pathogen regrowth in soils that had been spread with sewage biosolids (12). Researchers found that during hot, dry months, there were reduced levels of pathogens (fecal coliforms and salmonellae) in stored and spread sewage sludge, but that the concentrations of pathogens rose during the wet cool months that followed. In some instances, the pathogen regrowth was to levels higher than found in the initial tests. No informed consent: Farmers and rural residents are told that the sludge is treated for pathogen reduction. There is no requirement to explain the health risks to farmers or those who live near sludge spreading or storage sites.

Occupational health and safety issues related to sewage sludge are starting to be addressed with the recent Health Alert from the National Institute for Health and Safety. Documents like the Safety Alert issued by the Spokane Regional Health District in the State of Washington are increasingly common in the United States and Great Britain. (13). However, action on public health education on sludge lags behind the occupational health and safety requirements for sludge handlers. The public needs to be informed of the pathogenic risk posed by sludge transporatation, storage and spreading.

No storage: When rainy weather makes sludge spreading particularly risky for runoff and ground water contamination, most municipalities do not have adequate disposal alternatives for sewage sludge. The City of Toronto sludge has been evicted from the Halton storage facility, and the City of Toronto hauler is now storing sewage sludge in open piles in Ontario farmfields. The Ontario Ministry of the Environment has allowed the Toronto sewage sludge to be stored in huge open piles on farmland in Northumberland County near Warkworth (14).

\section{CONCLUSIONS}

Open field storage of sludge and sludge spreading near wells and surface water, increase the risk that sewage sludge pathogens will be transported to workers, farmers and neighbours, and increases the environmental risks of this wastedisposal practice. It seems unreasonable to offer the farm community 'free fertilizer' and promote its use when the public health risks associated with the land application of sludge have not been addressed. The case against land application does not stop with the issues posed by pathogens; other heath risks are associated with the elevation of heavy metals in the soils and foods, the release of mercury into the atmos- phere from sludge spreading and the presence of priority pollutants in the land-applied sludge.

We seem to have forgotten the public health lessons of the 1800 s and the underlying reason for sewage treatment plants themselves. The pathogen levels in sewage sludge are high and can even increase over time once the sludge is stored or applied to land. Land application allows sludge pathogens to be transported by weather events, and facilitates the spread of diseases to animals and humans. It is unreasonable to expect rural residents to tolerate exposure to these diseases in land, air and water. The Canadian Infectious Disease Society should be applauded for its call for a moratorium on sludge spreading until the risks to public health and the integrity of food are thoroughly evaluated.

\section{REFERENCES}

1. Webber MD, Singh SS. Health of Our Soils, Chapter 9, Contamination of Agricultural Soils. In: Acton DF, Gregorich LJ, eds. Toward Sustainable Agriculture in Canada. Ottawa: Centre for Land and Biological Resources Research, Research Branch, Agriculture and Agri-Food Canada, 1995.

2. Chauret C, Sharma R, Springthorpe S, Sattar S. The efficiency of the anaerobic digestion process in reducing the pathogen content of treated sludge of biosolids. Presentation to the City of Ottawa, September 1995.

3. Chauret C, Springthorpe S, Sattar S. Fate of cryptosporidium oocysts, giardia cysts, and microbial indicators during wastewater treatment and anaerobic sludge digestion. Can J Microbiol 1999;45:257-62.

4. Straub TM, Pepper IL, Gerba CP. Hazards from pathogenic microorganisms in land-disposed sewage sludge. Rev Environ Contam Toxicol 1993;132:55-91.

5. Nethercott J, Holness DL. Health status of a group of sewage treatment workers in Toronto. Can Am Ind Hyg Assoc 1988;49:346-50.

6. United States Department of Health and Human Services. Hazard ID 10: Workers Exposed to Class B Biosolids During and After Field Application, Publication No 2000-158. Washington: United States Department of Health and Human Services, 2000.

7. Schiffman SS, Walker JM, Dalton P, et al. Interface of human health and agriculture. J Agromed 2000;7:7-81.

8. Dowd SF, Gerba CP, Pepper IL, Pillai SD. Ecological risk assessment: Bioaerosol transport modeling and risk assessment in relation to biosolid placement. J Environ Qual 2000;29:343-8.

9. Ministry of the Environment and Energy and Ministry of Agriculture, Food and Rural Affairs. Guidelines for the Utilization of Biosolids and Other Wastes on Agricultural Land. Toronto: Queen's Printer for Ontario, March 1996.

10. Ontario Ministry of the Environment Certificates of Approval for land application of sewage sludge from Toronto's Ashbridges Bay Sewage Treatment Plant and Ottawa's Pickard Sewage Treatment Plant. Certificate of Approval S3123-37, Ontario Ministry of the Environment, Peterborough Office, June 20, 2001.

11. State of New Hampshire Rockingham County Superior Court, Joanne M Marshall et al v Wheelabrator Water Technologies Inc et al, Expert Witness Report of David L Lewis PhD (Web page summary). <http://www.friendsofthecreek.org/ expert_report.htm $>$ (Version current at August 12, 2001)

12. Gibbs $\overline{R A}, \mathrm{Hu}$ CJ, Ho GE, Unkiovich I. Regrowth of faecal coliforms and salmonellae in stored biosolids and soil amended with biosolids. Water Sci Technol 1997;35:269-75.

13. Fact Sheet: Biological Hazards at treatment Plants. <http://www.spokanecounty.org/health/EHS/brochures/ biologicalHazards.htm > (Version current at August 12, 2001)

14. Certificate of Approval, Ontario Ministry of the Environment, Peterborough Office, 2001. 


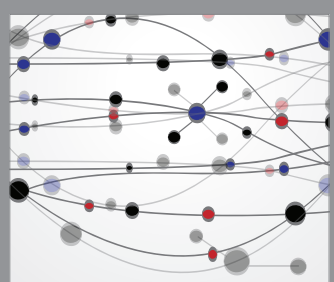

The Scientific World Journal
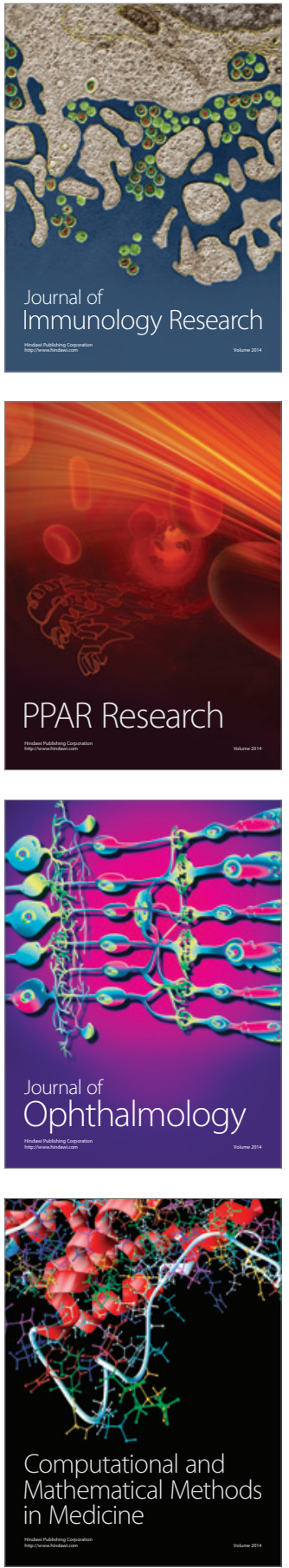

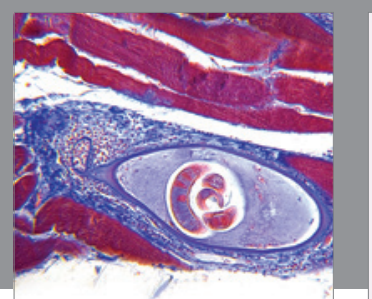

Gastroenterology Research and Practice

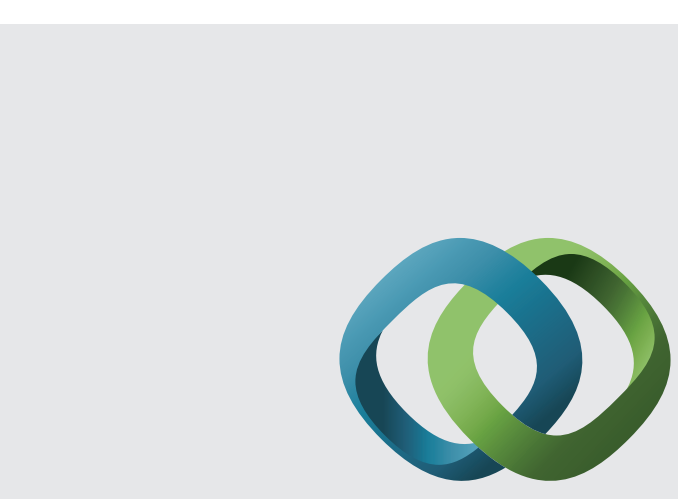

\section{Hindawi}

Submit your manuscripts at

http://www.hindawi.com
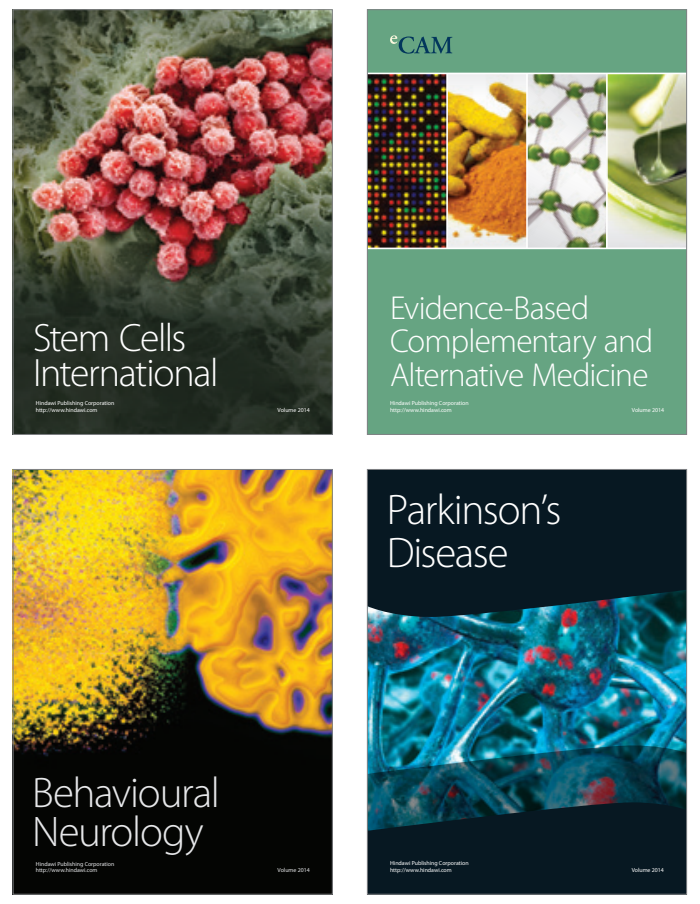
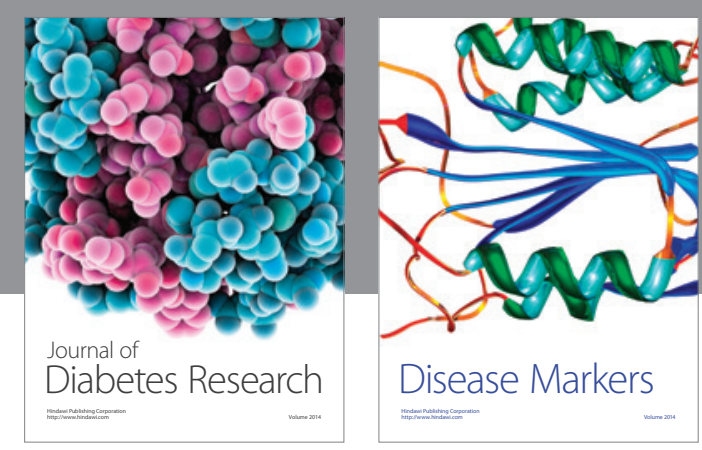

Disease Markers
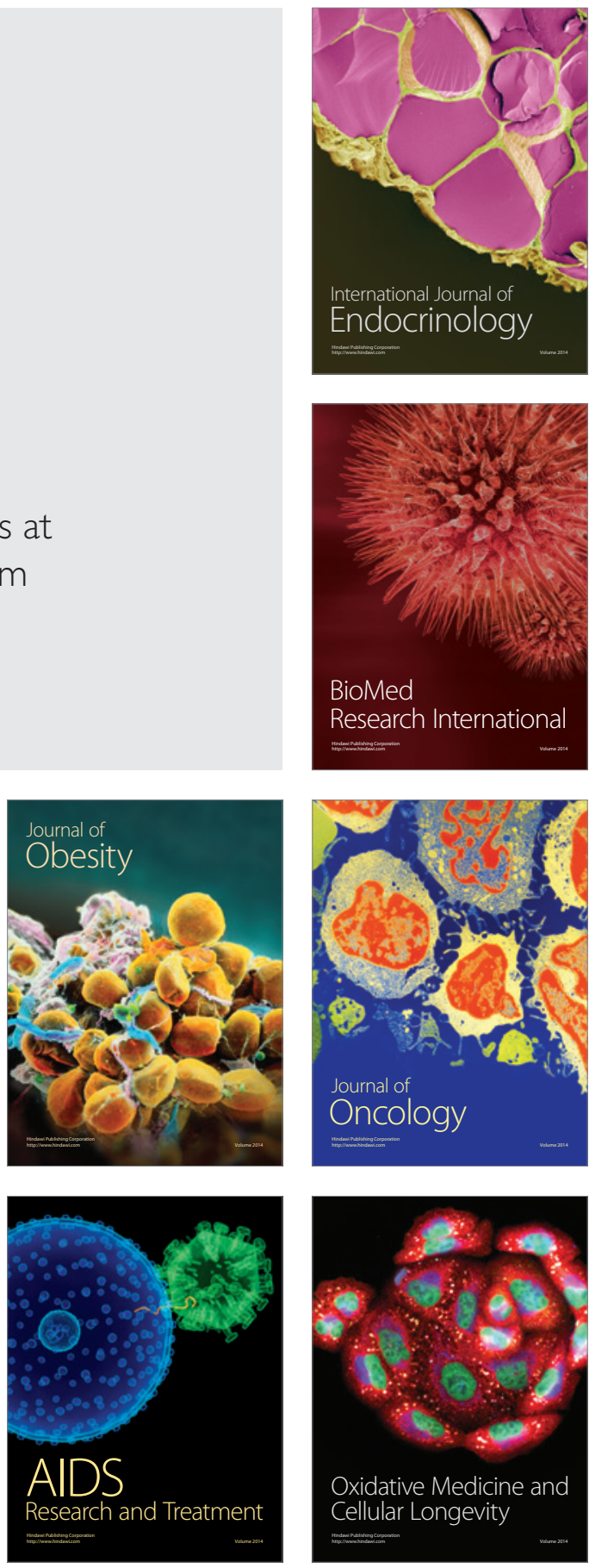